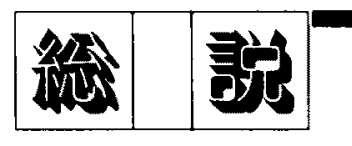

\title{
〔99〕原子力におけるヒューマンモデル研究の 現状と応用領域の展望
}

\author{
吉川 榮和 $* 1$, 古田一雄 $* 2$, 中川 庸雄 $* 3$, \\ 吉村誠一 ${ }^{* 4}$, 吉田一雄 $* 5$, 内藤 憲夫*6
}

\begin{abstract}
Review on Present State of Human Model Researches in Nuclear Engineering and the Prospect for their Industrial Applications
\end{abstract}

\author{
By Hidekazu YOSHIKAWA, Kazuo FURUTA, Tsuneo NAKAGAWA, \\ Seiichi YOSHIMURA, Kazuo YOSHIDA and Norio NAITO
}

\begin{abstract}
Reviews have been made on the researches and developments for human models in the field of nuclear engineering. Until now, the related works have been made mainly for the modeling of plant operator and operator crew in the control room, but also there arise new tendencies of extending the modeling works for maintenance field as well as for personnel training purposes.

The whole range of human model research is divided into the five areas of (a) modeling for machine system, (b) measurement and analysis of human information behavior, (c) modeling of human internal information process, (d) modeling of human interaction with machine system, and (e)that of between human themselves. The real examples of the human model developments as well as their methods, applications, and the model validations are described, and then, the further subjects and efforts are pointed out which would be needed for the broader industrial application of the human modeling.
\end{abstract}

KEYWORDS : human-machine system, man-machine system, human machine interaction, operator model, man machine interface, human models, human cognition, nuclear power plant, reactor operation, maintenance, training, nuclear engineering, educations

\section{I. はじめに}

原子カブラントは，近代技術の粋を集約した巨大技術シ ステムの典型で，いわば現代のピラミッドともいえる。最 近，技術システムの巨大化に伴い，様々な側面で「技術と 人間の関係」が社会問題化してきた。特に巨大技術システ ムの運用管理面では，ヒトと機械システムの接点(マンマ シンインタフェース)のあり方を，ヒトの原理を中心に再 考する「ヒューマンインタフェース」の視点がますます重要 になった。

筆者らは, マンマシンインタフェース向上のための技術 基盤として，機械と交流する人間行動の科学的捉え方，モ

*1 京都大学大学院エネルギー科学研究科 (Graduate School of Energy Sci., Kyoto Univ.)

*2 東京大学大学院工学研究科 (Graduate School of Eng., Univ. of Tokyo)

*3 (䐓) 原子力発電技術機構ヒニーマンファクターセンター (Inst. of Human Factors, Nucl. Power Eng. Corp.)

*4 (期) 電力中央研究所 ヒューマンファクター研究センター (Human Factors Res. Center, Central Res. Inst. for Elec. Power Ind.)

*5 日本原子力研究所 人的因子研究室 (Human Factors Res. Lab., Japan At. Energy Res. Inst.)

*6 保東芝原子力技術研究所 (Nucl. Eng. Lab., Toshiba Corp.) (1998年 10月29日 受理)
デル化を「ヒューマンモデル」と呼ぶことにして，すでに 「本誌」で1994年の時点の, 原子力におけるヒューマンモデ ル研究の基本的な考え方と方法論，当時の内外の研究状況 を紹介した (1)。本稿は, 約 5 年を経過した現在, ヒューマ ンモデル研究がその後どのような方に発展したか，その 成果と将来方向を再び展望する。

1994年の時点では，ヒューマンモデル研究は，欧米での マンマシンインタラクション(人間と機械システムの相互 作用)のコンピュータシミュレーションに関する幾多の先 行研究に触発され, 我が国の原子力発電に関わるヒューマ ンファクタ研究を行う公的機関において，いずれも七ュー マンモデル研究をその重点テーマとして組織的な研究が着 手された。なお，米国では，航空機のコックピットデザイ ンは, パイロットの“ヒューマンモデル”シミュレータで設 計していると, 筆者(吉川)は最近, Sheridan 教授(MIT) から伺った。動きの早い航空機の場合, パイロットには敏 速な対応が必要で, 反射行動的なのでモデル化もしやす い。しかし原子力の場合，プラント応答も革く，運転員の 対応には思考判断の要素が大きい。この辺が原子力の ヒューマンモデルの難しいところである。なお，米国航空 界でのヒューマンモデルではMIDASが有名で、これを原 子カプラント用に改造する研究が報告されている(2)。

その後, 欧米では, 原子力開発の全般的停滞を反映して 
か，せっかくの先行研究むその後とくに見るべき発展む見 られず，最近は我が国が，世界のヒューマンモデル研究を 先導する観がある。我が国でのヒューマンモデルの研究開 発は, 元来の方向であった, プラント運転員の運転監視行 動のモデリングと中央制御室でのマンマシンインタラク ションのコンピュータシミュレーションばかりでなく, ヒューマンモデルを運転訓練や機器保守点検作業の教育支 援システム(CAI)の開発へ応用する動きも見られるように なってきた。本稿では，我が国の最近の，このような ヒューマンモデル研究の現況を，その成果と今後の産業応 用の可能性を中心に論じることとしたい。

\section{II. 拡大するヒューマンモデルの枠組み}

原子力におけるヒューマンモデルの対象は，プラントの 中央制御室での運転員認知行動モデルの開発を中心課題と して出発し，最近はこれをもとに運転員のチーム行動のモ デリングや，さらには保守作業員の機器分解点検組立作業 のモデリングへも発展してきた。これらを包括した，原子 カのヒューマンモデル研究の一般的な枠組みは，第 1 図の ようになるが，そこには大別して次の 5 つの領域がある： (1) 機械システムのモデル化, (2) ヒトの情報行動の計測, (3) 人間の内部プロセスのモデル化, (4)機械とのインタラ クションプロセスのモデル化, (5)人間同士のインタラク ションプロセスのモデル化。以下，これらの研究領域を説 明する。

\section{1. 樴械システムのモデ化}

機械システムのモデルといえば，プラントを構成する 個々の機器の工学モデルや，それらで構成されるシステム のダイナミックシミュレータがまず想像されるが，これら ばかりでなく, 機器の分解・組立のための CAD デル, 機
器故障の测定·診断モデルなどもこの範疇に人る。これら は機械の物理を数学モデルとして表現してコンピュータモ デルとして構成するもので, いわば伝統的な工学領域での モデリングである。「機械システムのヒューマンモデル」で は，現実世界の人間と機械の種々のインタラクションにお いて，ヒトが機械をどのように頭の中でイメージし，操作 しているか，機械に対してヒトが抱くメンタルモデルをモ デル化する。メンタルモデルの表現では，機能・構造的側 面, 目標・手段的側面およびこれら相互の関連性, ヒトが機 械を操作する時に，機械の物理的振舞いを，どのような状 態遷移規則として捉えているかなど，明示的であれ，暗黙 的であれ，ヒトの知識形態を，ヒトから引き出して，知識 モデルとして表現する。

\section{2.ヒトの情報行動の計測}

これは現実世界の人間と機械の種々のインタラクション におけるヒトの情報行動を、ヒトとヒトとのインタラク ションむ含めて, 理解するための実験と計測である。 ヒューマンモデル構成と検証のための観測データ取得ばか りでなく，コンピュータモデルとして構成するオンライン 型ヒューマンモデル(後述)への, 有効な入力情報の抽出に す関連する。

\section{3.人間の内部プロセスのモテル化}

これは外界情報を, 感覚器官を通じて取得し, 知覚·認 知して行動を出力する, 人間行動の内部プロセスのモデル 化であり，いわば“狭義のヒューマンモデル”である。著者 らの既報 ${ }^{(1)}$ では, この部分のモデル化で考虑すべき内部 的な心理機構を, 第 1 図のうち, 知覚, 思考, 判断, 意思決 定に絞って論じているが, 最近のヒューマンモデル研究で は，ヒトの協同作業も問題となってきて，ヒトとヒトとの コミュニケーションのモデル化, 人間行動の下地をなす情

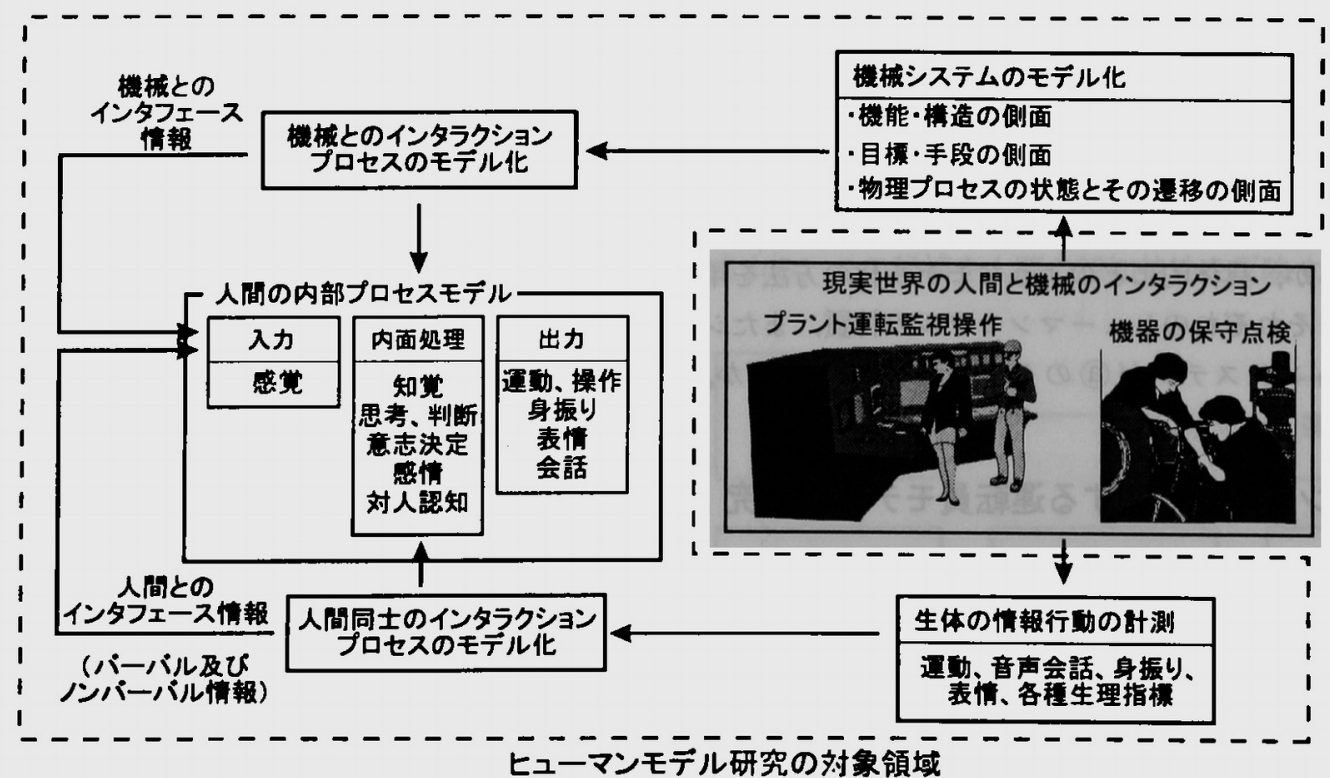

第 1 図 原子力におけるヒューマンモデル研究の対象と要素 
動などの感情要因や，他人の行動を理解する対人認知のも デル化もその範囲になってきた。

4. 機械とのインタラクションプロセスの モテル化

これは中央制御室での監視操作や，機器分解組立点検作 業の際の, 機械の「工学モデル」とヒトとのインタラクショ ンプロセスを，(1)に述べた機械の「メンタルモデル」を用 いて，前の (3)に述べるヒューマンモデルで解釈・使用でき る形式にモデル化する領域である。

\section{5. 人間同士のインタラクションプロセスの} モテル化

これは特にヒト同士のコミュニケーションをヒューマン モデルの対象にする場合に必要である。個々のメンバーの 役割分担や，例えば音声会話や身振り，表情などの，相互 コミュニケーションの形態加ら，ヒューマンモデルのうち の対人認知モデルに使用さ机る人間とのインタフェース情 報を，規定·抽出·使用するプロセスをモデル化する。

現実の原子力ヒューマンモデル研究においては，上述の (4)の狭義のヒューマンモデルを中心に，これら5つの要 素モデルを関連させたシステム化が行われている。また， コンピュータシミュレーションの形態には，(a)オフライ ン型(第 1 図の 5 要素の範囲内でのシステム化で, 実際の ヒトとは切り離されている場合)と，(bオンライン型(ヒ トの要素む入ってクローズドループになっている場合)の 2 通りがある。(a)の典型はプラントシミュレータと運転員 モデルを接続した人間機械系シミュレーションであり, 一 方，(bではヒトとの対話がないと意味がない教育用 CAI が実例である。（aでは必ずしもリアルタイムシミュレー ションは必要でないが，(bではリアルタイム化が必須と なる。

以下，第亚章においては，特にプラント制御室の監視制 御行動の運転員モデルとマンマシンインタラクションの総 合シミュレーションの研究開発動向について, 我が国の代 表的なプロジェクト研究事例を紹介し，一方，第I章にお いては，その他の研究開発のうち，特に新しい応用を指向 している研究事例を紹介する。これらの研究事例の紹介で は，ヒューマンモデルの 5 つの要素で，どのような応用を 意図しているか，具体的にどのようなモデル化の方法を用 いているか，それぞれのヒューマンモデルの特質，またシ ミュレーションシステムが(a)のタブか(1)のタイプか, 述べる。

\section{III. プラント制御に関する運転員モデルの研究}

\section{1. 東京大学における状況}

(1) 運転員認知シミュレーション(OCCS)

これまでにプラント運転員の認知ンステムをモデル化 し，認知行動の計算機シミュレーションを行うシステム， 運転員認知シミュレーション(OCCS)の開発を行ってき た。OCCSは人間機械系統合シミュレーションによって実
験的手法を補完し，プラント人間機械系の設計評価を行う ことを主目的とするシステムである。 OCCSのヒューマン モデル(HM) 開発は意思決定の梯子モデルを記号処理技術 によって計算可能にすることから出発したが，黒板制御モ デルの採用によって認知モデルに必要な情況決定性を付与 している。また複数の知識ベースと黒板を有し、集団行動 へも適用可能である。

OCCS は，時間传存TMSによる翻意抵抗之複数資源も デルに基づく運転員の心的負荷の評価 ${ }^{(3)}$, 集団問題解決の モデル化と学習勃果の分析 ${ }^{(4)}$, 異常診断認知実験によるも デル検証 ${ }^{(5)}$ ，環境相互作用を考虑した運転員行動のシミュ レーション (6)などの研究に適用され，人間機械系統合シ ミュレーションの有効性を確認するととすに，モデルの改 良が行われた。なお，OCCSの詳細については既出の解説 を参照されたい(7)(8)。

(2) ヒューマン・コミュニケーション

情報技術の発展とともに，原子力をはじめとする高度科 学技術システムでは高度の自動化が推進され，システムの 信頼性向上に貢献する一方で，人間と機械の関わり方にお いて従来見られなかった新たな問題が生じている。この問 題の最大の原因は，現在のマンマシンインタフェースの機 能が情報提示と指令伝達の域を大きく越えるものではな く，人間同士のコミュニケーションに見られるような相互 理解が不足しているためと考えられる。そこでこれまで得 られたHM研究の成果を活用し，この問題の解決を目指す ことは意義のあることといえるだろう。

ここで人間と機械のコミュニヶーションを考える前に, 人間同士のコミュニケーションについて考えてみることに しよう。我々はなぜ人の言動を理解し，協調的行動をとれ るのだろうか。それは我々各人が頭の中にHMを持ってお り，認知過程を心的にシミュレーションすることによって 人の言動に説明を加えられるからと考えられる。HMは健 常な人間なら噰もが持っているもので，認知システム工学 の専門家だけのものではない。すち万ん皆が同様な HMを 持っているとは限らないし，素朴理論的 HMは専門家の HM と異なるかむしれない。しかし我々はHMの心的操作 を通して人の言動を理解しており，HMなくして円滑な対 人コミュニケーションは望めない。

このような HMを我々はどのように構築すべきか。人間 以外の対象について，我々は対象の振舞いを長期に観察す ることによって対象の振舞いの特徽を記述する変数間の相 関関係を発見し，次に得られた相関関係を因果的に解釈 し，最後にその因果関係を自分の期待や意図に沿って目的 論的，操作的に構造化する経過をたどって対象のメンタル モデルを構築する(9)。これは内部の仕組が司瞀けない対象に ついて，外部から観测可能な情報のみに頼った間接的方法 である。対象が人間の場合にもこのような行動主義的方法 は有効だろうが，HMの場合にはこれよりはるかに直接的 方法がある。それは人間の認知がそれ自身を内観できると 
いう特性を利用するもので，これによってHM構築は行動 主義的制約から自由になる。

我々は自分が今何を考えているかを認識できるし，現在 の考えに至った認知過程を説明することもできる。このよ うに我々の認知が自己言及的であることは, 心理学, 人工 知能, 社会学などの分野で以前から重大な関心を呼んでき $た^{(10)(11)}$ 。むちろん, 我々が意識しているのは逐次的に行 われる高次認知過程のごく一部に過ぎないし，その背後に は意識に上らずに並列的に行われる膨大な認知過程が存在 する。また意識されるのは認知過程そのものではなく，後 見的説明であるともいわれており，心理学では内観報告の 解釈に注意が必要とされてきた ${ }^{(12)}$ 。人間行動の決定機序 を解明する際にはこれらを差し引いて考える必要がある が,コミュニケーションの場合には人間の認知が自己言及 的であることは次の 2 点で決定的に重要な意味を持つ。

第 1 に，すでに述べたように自己の認知過程を内観する ことにようて, 外部観察に基づく推測に頼ることなしに HMを直接構築できることである。こうしてできた HM は 自分の認知のモデルであってコミュニケーション相手のモ デルではない。しかし人間であれば人あ自分と同様に思考 するはずだという思い込みに基づいて，自分のモデルを他 人に適用して相手の言動を理解するのである。第 2 に, 内 観の結果を人に報告することによって，言動を決定するに 至った自己の認知過程について直接的証拠が提供できる。 その結果, 表面的行動の観察とHMを使った推論にまかせ るよりあ，自分の言動の合理性を正しく理解してもらえる 可能性は高まる。我々は自分の行動をどうしてあ理解して もらいたいとき, 結論だけでなくその認知過程を他人に説 明して相手の認知を自分と同調させようとする。

そこで発話コミュニケーションが後者の機能を有するこ とを示唆する例として, 2 水槽系温水供給プラント DURESS 被験者 2 人で協力して運転してもらい，2人 の発話を観測, 操作実行, 解釈, 計画, 注意, 情況認識, 動機づ けの 7 種類の認知過程に関するすのに分類した結果を第 2 図に示す。図は 3 チームの発話の合計を 4 つの実験シナリ オごとに示しており, シナリオ 1,2 は事前練習用マニュ アルに記載のある異常のみを含む想定内シナリオである が, シナリオ 3,4 はマニュアルに含まれない異常を含む 想定外シナリオである。解釈と計画の発話は外部から観察 不可能な認知過程の深部に関する情報交換を担っている が，その全発話中の割合は $54 \%$ とかなり高率であり，また

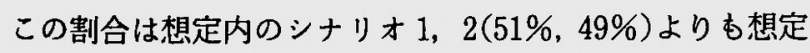
外のシナリオ $3,4(58 \%, 58 \%)$ で有意に高い。このように 人間同士のコミュニケーションでは, 認知システムに入力 される情報の共有ばかりでなく, 認知過程そのものの共有 が重要な役割を担っており，想定外状況ではそれが一首重 要なことがうかがわれる。

\section{(3) HM研究の方向}

以上より，機械と人間の協調的コミュニケーションを実

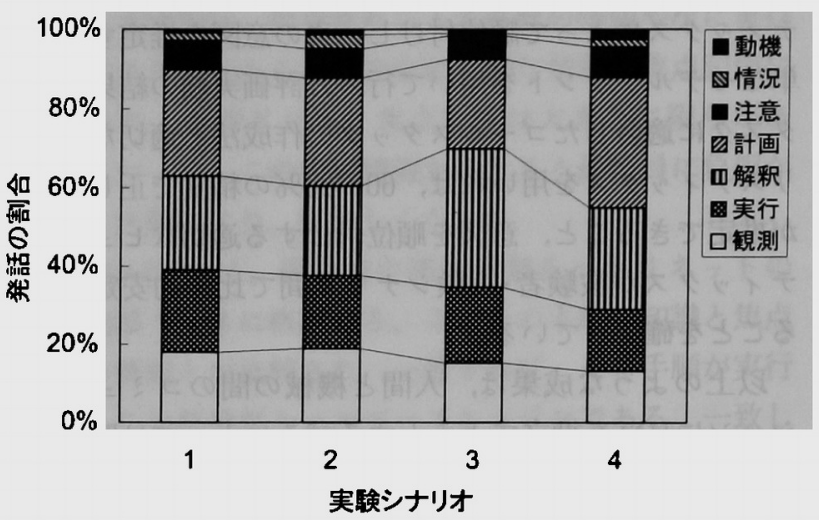

第 2 図 チームによるDURESS 運転での発話

現するためには，機械が人間同様にHMを利用して人間の 言動を理解できるとともに，自分の言動を理解してあらう ための説明を行えるようにすることが不可欠のようであ る。これは機械が HMに基づいて人間と同じ方法で問題解 決することを要求するものではない。むしろ多様性による 高信頼性達成の点では, 形式的で厳密な理論や網羅的探索 など，人間の思考と異なり人間の思考を相互補完するよう なモデルで問題解決させた方が望ましい。しかしコミュニ ケーションにおいては, 人間のコミュニケーション原理に 近くなければ相互理解が非常に困難になる。

HMをコミュニケーショ資源とする技術開発の第一歩 として, プラント運転員の意図理解の研究を行ってい る(13)。これは運転員が対象プラントや自分のタスクに関 して持っている知識のモデルに基づいて，運転員が行った 操作の目標と手順とを意図として同定する手法である。運 転員の知識モデルは，対象プラントの挙動の形成機序を定 性的な因果関係に基づいて記述した機構的知識と，運転操 作タスクを手段目標関係に基づいて階層的に記述した操作 的知識からなると仮定している。

意図推論は第 3 図に示す方法で行われる。まず，プラン 卜状態の監視結果から運転操作の目標となりうる状態を数 え上げて，ゴールスタックと呼ぶリストを作る。ゴールス タック上の目標に対して，これを達成する手順を知識モデ ルから生成する。この手順を運転員が実際にとった操作と 比較し, 運転員の意図の候補をデフォルトルールとして作 成する。この候補を人間の認知特性を反映するヒューリス

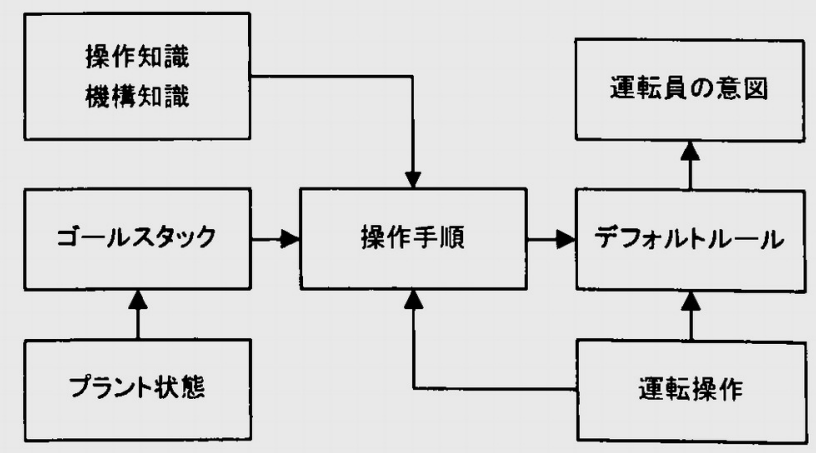

第 3 図 意図推論の方法 
ティックスによって順位付けし，真の意図を推定する。簡 単なモデルプラントを用いて行った評価実験の結果, 要求 タスクに適合したゴールスタックの作成法と適切なヒュー リスティックスを用いれば，60〜80\%の精度で正しい意困 が推定できること，意図を順位付けする適切なとューリス ティックスが被験者・実験シナリオ間で比較的安定してい ることを確認している。

以上のような成果は，人間と機械の間のコミュニケー ションにHMを役立てようとする試みにとっては明るい材 料ではあるが，まだ研究は端緒についたばかりといってよ い。現状ではOCCSで開発されたモデルのごく一部の概念 を考虑しているに過ぎないし，意図推論の方法にあ改善の 余地が大きい。また 2 層構造の運転員知識モデルは十分で なく，構成空間, 因果空間, 状態空間, 目標空間の 4 層への 拡張を提案している(14)。

さらに人間の言動の意味するところはそれが行われる情 況に埋め込まれており，同じ言動であっても情況が異なれ ば意味が全く異なることがある。したがって，どれだけ詳 細な情況が参照できるかが解釈にとって重要である。この モデルによる意図推論では，プラント状態の推移と過去に 行われた操作しか考慮していないが，人間ではこれに加え て発話, 位置, 視線方向, 身振りや顔の表情までコミュニ ケーションに利用しており，これらが形成する情況におい て人の言動が解釈される。しかし機械による情況のセンシ ングは頒弱であり、このために人間とのコミュニケーショ ンに障害が生じることが少なくない(11)。したがって HM や推論手法の改良ばかりでなく，情況という概念の明確化 や効果的な情況センシング技術の開発む重要な課題である といえよう。

\section{2. 原子力発電技術機構における状況}

財原子力発電技術機構のヒューマンファクターセンター では，通産省の委託事業の一部としてヒューマンファク ター関連技術の開発を行っている。ここでは，ヒューマン モデルに関連するものとして，認知資塬不足による過誤発 生をモデル化したCAMEOとシミュレーションによって MMIの評価を支援するSEAMAIDの 2 件を紹介する。

（1）認知盗源不足による過誤発生モテル(CAMEO)

人間の情報処理過程では，「認知資源」を必要とする。こ こで，認知資源とは，認知処理を遂行するのに必要な注 意, 努力, 記憶容量等を含めた概念であり，「量」として取り 扱えるものとする。また，難しい情報処理過程は多くの認 知資源を必要とするが，認知資源量には限界があり，それ を越えて使用することはできない。認知資源不足が発生す ると，正常な認知処理ができなくなり，人的過誤(エラー) の発生につながる。CAMEO (Cognitive and Action Modeling of Erring Operator) ${ }^{(15)}$ は，このような考えを 基に開発したシミュレーション用のヒューマンモデルであ る。第 4 図にモデルの枠組みを示す。

原子カプラントの中央制御室で操作を行う運転貝を考え

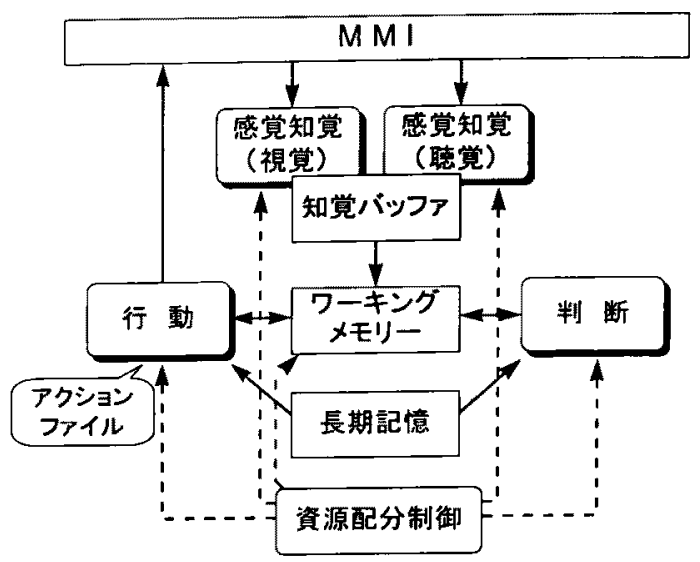

第 4 図 CAMEOの構成

た場合，感覚知覚モジュールが制御盤等のインタフェース (MMI)功の情報を取り込み，それを知覚バッファに一 時的に格納する。感覚知賞モジュールは，視覚と聴賞で別 のモジュールにしてある。このモジュールを夷行するため の資源が不足すると，知覚バッファの更新が不充分にな り, 情報の見落としが発生する。

判断モジュールは, ワーキングメモリー内の情報と, 長 期記憶内の「戦略(処理方法の定義)」を用いて, 観察, 診断, 対応行動の決定, 評価等を行う。決定された対応行動は ワーキングメモリーを通して行動モジュールに渡される。 充分な資源がない場合には，正しい戦略を用いることがで きず，短絡的な判断をしてしまう。

行動モシュールは，あらかじめ定義しておくアクション ファイルを用いて，判断モジュールが決定した行動を実行 する。アクションファイルには，必要な資源量，そのアク ションの前にするべき操作(条件操作)，本来の目的の操作 が定義されている。資源不足が起こると，条件操作の実行 を忘れたり，上り少ない資源量で実行できる別のアクショ ンファイルを選択してしまう等のエラーが発生する。

与えられた総資源量の配分は，資源配分制御がコント ロールする。すなわち，各モジュールからの必要資源量を 集計し，その結果が総資源量より少ない場合は，要求通り の資源量を，総資源量より多い場合は，資源配分ポリシー によって配分量を決定する。資源配分ポリシーは，個人差 を表すために導入したすので，一様配分，感覚知覚優先，判 断優先, 行動優先の 4 種類を用意した。

CAMEOは,リアルタイムエキスバートシステム構筮 ッールG $2^{(16)}$ を用いて EWS 上に作成した。本モデルの妥 当性は, 意図的に難易度を調整した被験者実験とシミュ レーション結果を比較して確認した ${ }^{(17)}$ 。CAMEO がエ ラーを起こさずに正しくタスクを遂行するために必要な最 小資源量(必要最少資源量)の傾向が，難易度の高低と一致 した。また，総資源量を減らしていくと，難易度が高い課 題からエラーを起こしやすくなることも，実験の傾向と一 致した。 
CAMEOを用いて，インタフェース設計案評価を武み た。2ループの加圧水型軽水炉簡易モデルを用い, CAMEO が在来型の MMI と 2 種類の CRT を主体とする $\operatorname{MMI}$ (プラントパラメータを系統ごとに階層化した機能階 層型と異常事象ごとに対応画面を用意したタスク型)を用 いて課題に対応する様子をシミュレートした。評価指標と しては，前出の必要最少資源量と認知裕度限界(資源不足 が起こらない最少の総資源量)を用いた。第 1 表は認知裕 度限界の例である。それぞれ值が小さいほど運転員への負 担が小さい。課題としては, TRP0が最も簡単で, TRP2 が逆に困難なこと、インタフェースとしては, タスク型の CRTインタフェースが最良であることを示している。

（2）シミュレーションによるMMI評価手法 (SEAMAID)

原子カプラントの中央制御盤の製作にあたっては，設計 案の段階で検討評価を十分に行い，質の高いインタ フェースを製作することが肝要である。ここで紹介する SEAMAID(Simulation-based Evaluation and Analysis support system for MAn-machine Interface Design) ${ }^{(18)(19)}$ は, EWS上で動作するシステムで, 評価対 象のインタフェースを通してプラントを運転する運転員の 行動を模擬し，その様子から，インタフェース設計案の問 題点抽出を支援するあのである。模擬するインタフェース の变更が容易なので, 設計時点で絽返し評価を行うことが 可能である。

SEAMAID は，機能的には，運転員の行う異常事象対 応を模擬するシミュレーション部とシミュレーション結果 を解析するエラー要因分析器に分かれる。シミュレーショ ン部には, プラントシミュレータ, MMIシミュレータおよ び運転員シミュレータがある。運転員シミュレータは，異 常事象検知後の事象診断と運転手順書に忠実に従う運転員 の対応行動を模擬する。シミュレーション中の運転員の位 置, 主要なプラントパラメータ, 運転員から見たインタ フェースの様子(運転員の視野)等を記録しておき，それを 基に, エラー要因分析器がインタフェース評価のための情 報を提供する。

運転員シミュレータは, 第 5 図に示すように, Reason が提唱した認知モデル(20)に基づいている。このモデルで は，短期記憶を周辺記憶と焦点記憶に分けて考える。周辺

第 1 表 CAMEOによるシミュレーション結果(認知裕度限界)

\begin{tabular}{lccc}
\hline \multirow{2}{*}{ 課 題 } & \multicolumn{3}{c}{ インタフェースの種類 } \\
\cline { 2 - 4 } & 従来型 & 機能階層型CRT & タスク型CRT \\
\hline LOCA & 105 & 85 & 85 \\
CVCF & 95 & 95 & 95 \\
TRP0 & 65 & 50 & 40 \\
TRP2 & 120 & 110 & 110 \\
\hline
\end{tabular}

LOCA：1 次系湜洩の判別。 CVCF：充てん制御并開固着の判別

TRP 0 : 補助給水ポンブ自動起動確認

TRP2：㭪助給水ポンプトリッブ検知
記憶に入る情報は, 目や耳から入る外界の情報や次に実行 すべきタスク名である。その中の重要な情報が焦点記憶に 取り込まれ，処理される。焦点記憶は大きさに限りがあ る。したがって，この中の情報が増えると運転員に負担が かかった状態となり，好ましくない。

SEAMAIDでは, 異常時の運転手順をぺトリネットの 形式で知識ベースに格納する。これらの手順の知識と焦点 記憶内の情報之が比較され，一致すれば，その手順が実行 される。この部分がルールベースエンジンである。一致し ない場合は, 診断エンジンが事象診断を行って対応手順を 決め, ルールベースエンジンで処理できる情報(対応手順 名)として, 焦点記憶に返す。この時,「診断のために計器 を見る」等の運転員の動作は, 診断エンジンからの依頼で, ルールベースエンジンが実行する。このように, ルール ベースエンジンと診断エンジンとの連携動作により, 事象 診断と手順書に従う対応行動が模擬される。

シミュレーションで得られた短期記憶内の情報量変化の 例を第 6 図に示す。80 130s で情報量が増加しているが, このような部分で運転員は大きな負担を感じることにな る。

現在は, 単独の運転員が異常事象に対応する様子が模擬 できる。さらに運転員チーム行動の模擬ができるように改 良を進めている。また, 診断エンジンについては, 京都大 学吉川研究室の協力を得て開発・改良を進めており, 現在 までに事象診断時間のバラッキが再現できるようになって

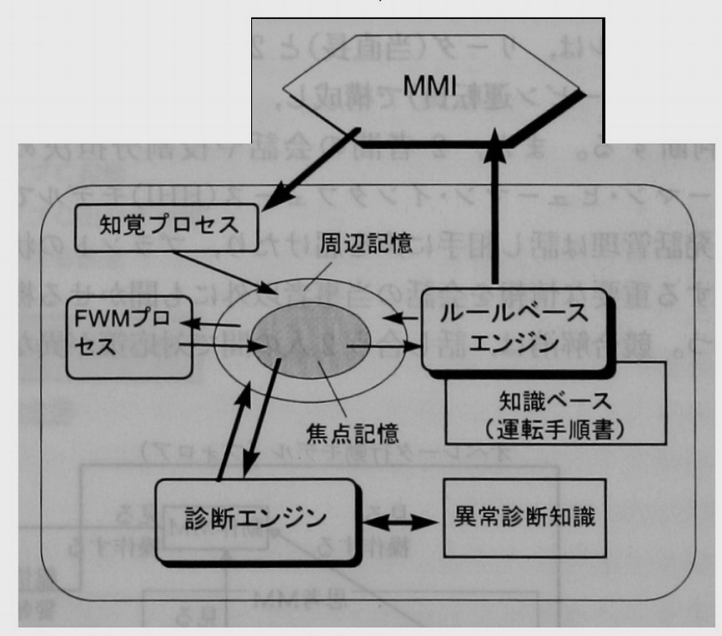

第 5 図 SEAMAIDの運転員シミュレータ内の情報処理

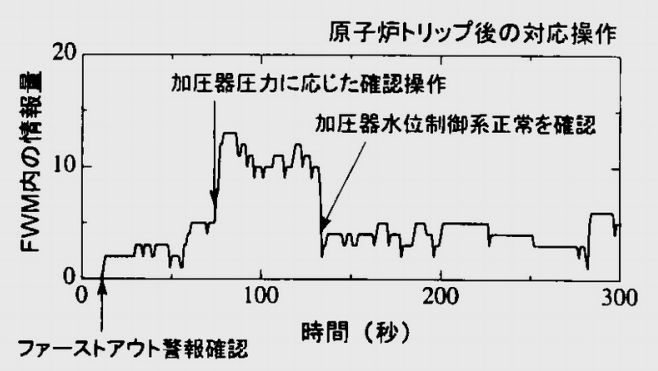

第 6 図 焦点記憶 $(F W M)$ 内の情報量变化の例 
いる。今後む改良を重ね，人間信頼性デー夕(異常事象検 知後の経過時間と事象診断未終了の割合との関係)の計算 を試みる予定である。

\section{3. 電力中央研究所における状況}

賏電力中央研究所七ニーマンファクタ一研究センター では，高度化・多様化する原子カプラントの中央制御室に お㚈るヒニーマンエラーの発生過程を解明し，その防止対 策に資するため，個々の運転員の思考過程や複数の運転員 から構成される運転チームの意思形成過程をモデル化する 研究(前者をオペレー夕行動モデル，後者を運転チーム行 動モデルと呼ぶ）また，これらを統合し，計算機上に構 築したシミュレーションシステムをSYBORG (Simulation System for the Behavior of an Operator Group) $の$ 開発を行っている(21)(22)。

（1）思考過程のモテル化

(a) 運転チーム行動モデル

原子カプラントにおいて, 運転員は役割分担(当直長, 原子炉運転員, タービン運転員など)に応じて情報を処理 し，行動する。例えば，原子炬運転員/タービン運転員は それぞれ原子炬側/タービン側の制御盤情報を入手・処理 し，当直長に事実関係の報告や操作に関する意見を具申す る。当直長はこのような情報を各運転員加ら入手・処理す ることによりチーム全体の動きを統括し，チームとして の意見を取りまとめる。本研究では，このような各運転員 やチームとしての振舞いを勘案し，第 7 図のような運転 チーム行動モデルを考えた。

このモデルは,リータ(当直長)と 2 人のフォロア(原子 炬運転員, タービン運転員)で構成し，それぞれが情埌を認 知・判断する。また， 2 者間の会話や役割分担決めは ヒューマン・ヒューマン・インタフェース(HHI)モデルで行 う。発話管理は話し相手に声を届けたり，プラントの状態 に関する重要な情報を会話の当事者以外にあ聞加せる機能 を持つ。競合解消は, 話し合う 2 人の間で対応策が異なる
場合，どちらか一方の対応策を選択する機能を持つ。ま た，役割分担は，仕事の割り振りを決める機能を持つ。

(b) オペレータ行動モデル

運転チーム行動モデルを構成する要素がオペレータ行動 モデル(リーダと 2 人のフォロア)である。このモデルは第 7 図に示すように，注意力，思考，動作(フォロアのみ)，発 話の 4 つのマイクロモデル(MM) と短期記憶, 中期記憶, 長 期記憶で構成する。各構成要素の機能は以下の通り。

・注意力 $\mathrm{MM}$ ： 外部情報(盤/音声情報)に対するフィ ルタとして鼽く。

- 思考 MM： 外部情報之中期記憶, 長期記憶を基に, 現在何が起きているかを理解し，メンタルモデルを作 成あるいは更新する。

・動作 MM：動作意図(例えば，ある操作を行いたい など)の実行や反射的な動作（警報が鳴ったら見るな ど)を行う。

・発話 MM： 発話意図(例えば，警報の内容を確認し てほしいなど)の実行や反射的な発話(確諗要求に対す る返事など)を行う。

・短期記憶： 注意力 $\mathrm{MM}$ モデルと思考 $\mathrm{MM}$ の間にあ り，外部情報に対するバッファの役割を果たす。

・中期記憶：外部情報に基づき, 運転員の状態予测 (メンタルモデル)が格納される。メンタルモデルは新 たなイベント(撆報など)が発生するたびに更新され る。

・長期記憶：警報の種類や操作の内容・タイミングな どが格納される。

(c) 運転員のメンタルモデル

トラブル発生時に運転員が何を考えて行動するかを正確 に知ることは難しい。しかし、シミュレー夕実験とその後 のインタビュー結果などによると，運転員は「将来を予測 し，事態の悪化を防ぐような対応操作を行う」あのと考え られる ${ }^{(21)}$ 。そこで，本研究では第 8 図のようなメンタル

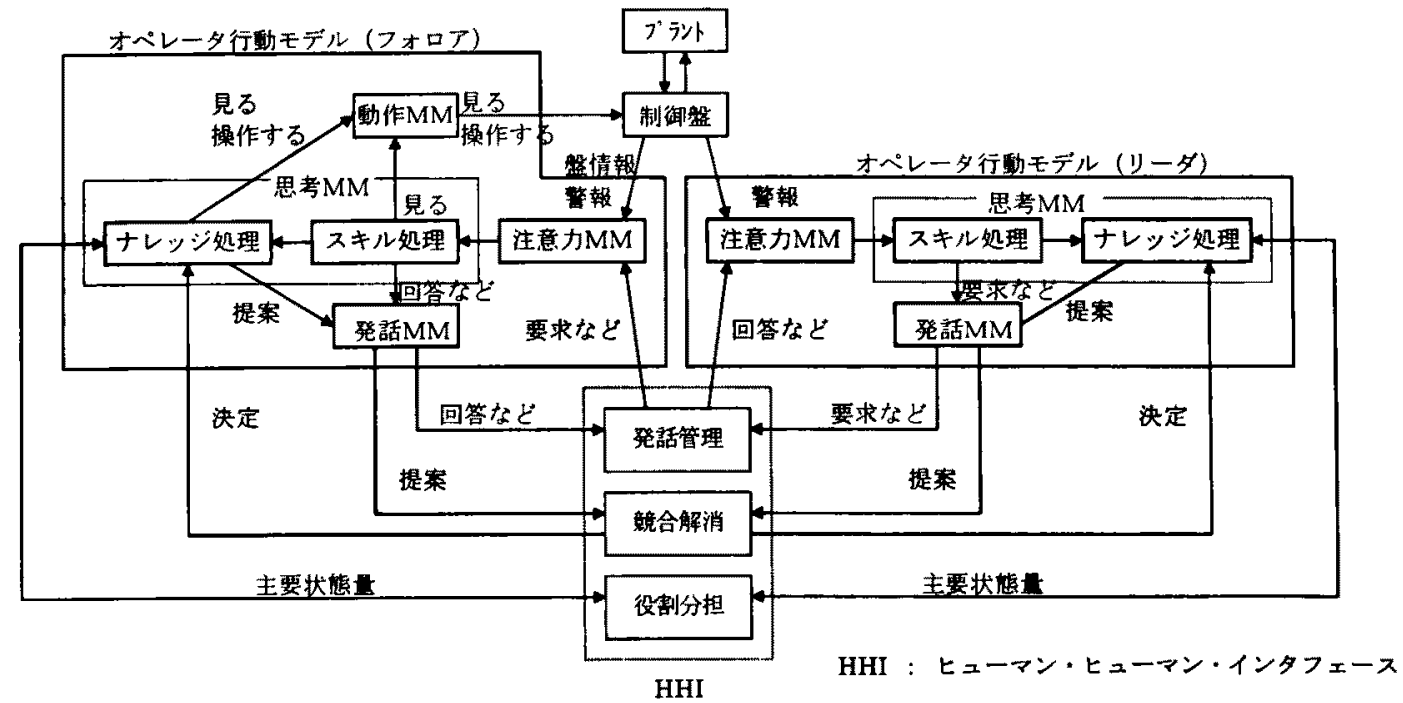

第 7 図運転チーム行動モデルSYBORGの基本概念 
モデルを仮定した。すなわち，警報レベルのイベント （Event 1)が発生したとすると，運転員は自分の長期記憶 を利用し，思考 MMでメンタルモデルを生成する。この 中で, 事象の原因は何か(Cause 1 または Cause 2), 何も 対応操作をしなければ, 事象はどのように進展していくだ ろうか(Event 2, Event 3など)と考える。ここで，各イべ ントに関連する状態量は一般に複数ありこのうちで最も 関連の強いむの(重要なあの)を主要状態量と名付け, 運転 員はこれを監視する。このようなイベントと関連状態量と の関係あるいはどの関連状態量を主要状態量とするかは個 人の長期記憶に依存する。ここで，運転員が行う対応操作 として 2 種類の対応(当面の対応，緊急対応)を考えた。前 者は,「警報が鳴った時, 事象緩和のためにとりあえず行 う対応」, 後者は,「次のイベントが起きないよう主要状態 量がランドマーク值(この値す各人の長期記憶に保持され る)になった時に行う对応」と定義した。

以上のモデル化に対する考え方によると，各マイクロモ デルや記憶はプラントの状況に応じ，臨機応変に起動しな ければならない。そこで，本研究ではこのような複雑なシ ステムの記述に適した OMT (Object Modeling Technique)を用いてシミュレーションシステムを構築した。

(2) シミュレーション結果

簡易 BWR プラント(電気出力約 58 万 $\mathrm{kW}$ ，発生マルファ

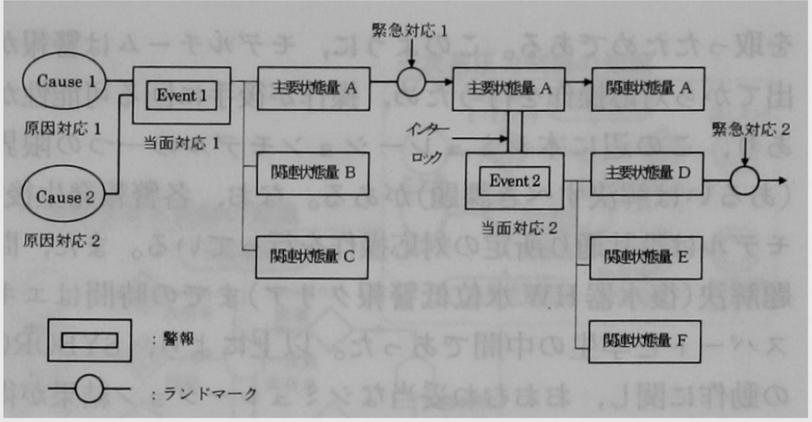

第 8 図オペレータ行動モデルのメンタルモデル

ンクション数約20)を用いて SYBORGの検証実験を行っ た。用いたマルファンクションは「復水ポンプ後の配管漏 洩」であり，モデル,エキスパート, 学生それぞれのチーム パフォーマンスを比較した。なお,このマルファンクショ ンは, 漏洩により復水器ホットウエル $(\mathrm{HW})$ の水位が低下 し，何もしなければ原子炉スクラムに至る事象である。結 果を第 9 図に示す。モデルと被験者の対応操作上の大きな 違いは, 復水器 $\mathrm{HW}$ 水位を回復させるために行う「復水補 給弁開」操作のタイミングである。モデルチームは復水器 低撆報が出てから上記操作を行った。一方，エキスパート チームはこの警報が出る前に当該操作を行った。これはエ キスパートチームが最初の警報(タービン建屋漏洩警報)が 出た時点で復水器 $\mathrm{HW}$ 水位低撆報を予想し, 早めの対応

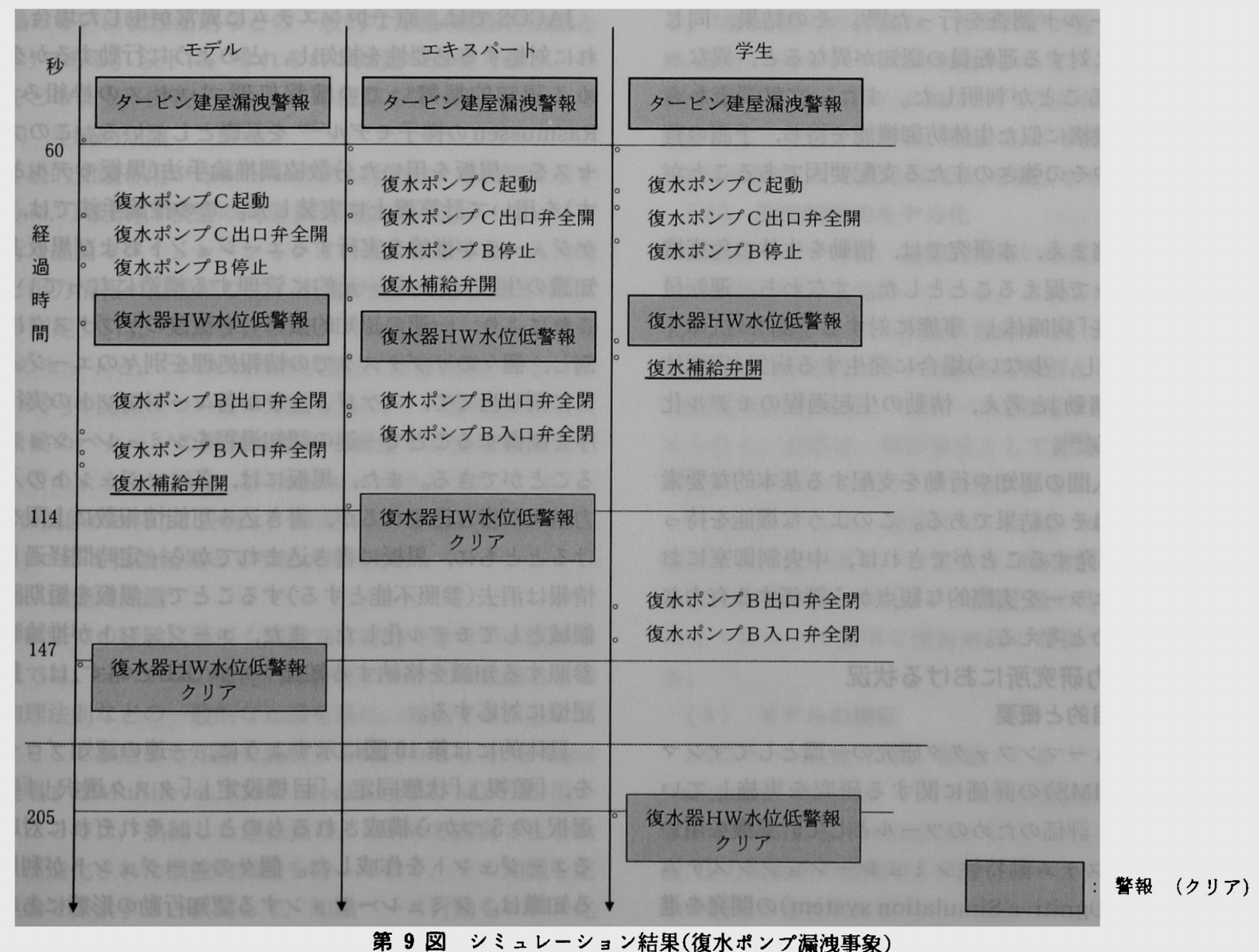

日本原子力学会誌、Vol. 41, No.1（1999） 
を取ったためである。このように，モデルチームは警報が 出てから対応操作を行うため，操作が後手に回る可能性が ありこの辺に本シミュレーションモデルの一つの限界 (あるいは解決すべき課題)がある。なお，各警報発生後， モデルは設計通り所定の対応操作を行っている。また，問 題解決(復水器 HW 水位低警報クリア)までの時間はエキ スパートと学生の中間であった。以上により，SYBORG の動作に関し，おおむね妥当なシミュレーション結果が得 られた。

\section{(3) 今後の展望}

トラブル発生時の中央制御室における婯囲気が, 通常時 と違うことは容易に想像できる。また，このような雾囲気 が高じて運転員の判断や行動に影響した例 ${ }^{(23)}$ も報告され ている。したがって,トラブル時における運転員の思考過 程や行動を正しく評価するためには，このような雾囲気や 自分の内部状態が運転員に与える影響，その結果としての エラーならびにトラブル体験による運転員の知識の強化 (学習)などを人間が本来持っている機能として SYBORG に取り込んでいく必要がある。当センターでは，これら 「情動」「「ラー」,「学習」を「人間らしさ」と捉え，モデル開 発の第 2 段階として，これら人間らしさのモデル化検討を 行っている。

これらの中から，一例として情動について簡単に紹介す る。本研究では, 情動メカニズムの基本概念を提案し，そ れに基づくフィールド調查を行った ${ }^{(24)}$ 。その結果, 同じ 状況下でもそれに対する運転員の認知が異なると，異なっ た情動が生起することが判明した。また，文献調查から は，情動が免疫機構に似た生体防御機能を持ち，予測の有 無が情動の生起やその強さの主たる支配要因であることが 判明した ${ }^{(25)(26)}$ 。

以上の調查を踏まえ，本研究では，情動を生体の免疫機 構とのアナロジーで捉えることとした。すなわち，運転員 が遭遇する事態を「病原体」, 事態に対する予湘を「抗体」, 抗体がない(ないし，少ない)場合に発生する病気(病原体 が増殖する)を「情動」と考え, 情動の生起過程のモデル化 検討を進めている ${ }^{(26)}$ 。

情動や学習は人間の認知や行動を支配する基本的な要素 でありエラーはその結果である。このような機能を持っ たSYBORGを開発することができれば，中央制御室にお けるヒューマンエラーを奏際的な観点から評価する有力な ッールになるものと考える。

\section{4. 日本原子力研究所における状況}

\section{(1) 開発の目的亡概要}

原研では，ヒューマンファクタ研究の一環としてマンマ シンシステム(MMS)の評価に関する研究を実施してい る。そのなかで，評価のためのッールとして計算機を用い たマンマシンシステム動特性シミュレーションシステム JACOS(JAeri COgnitive Simulation system)の開発を進 めている(27)。開発の目的は，異常時の対応においてマン
マシンシステムのパフォーマンスに影暨を及ぼす種々の要 因を解明するのに役立つ情報を提供できる計算機プログラ ムを開発することにある。このシステムは,マンマシンイ ンタフェース(MMI)の特性, 運転員が持つ知識などを解析 条件として, 異常発生時において運転員が行う状況の把 握, 対応策の決定などの認知過程のシミュレーションを目 指している。これまでにシステムの原型版を作成した。作 成したシステムは, 異常時の原子炉システムの挙動をシ ミュレーションする原子炉モデルとそのときの運転員の認 知的振舞いをシミュレーションする運転員モデルで構成さ れる。運転員モデルは，人工知能技術を利用して新たなプ ログラムを開発した。原子炣モデルとしては, 詳細熱水力 解析コードRELAP5/MOD2 ${ }^{(28)}$ とPWR 簡易シミュレータ の計算プログラムを結合したプログラムを作成した。前者 が原子炬システムの主要な核熱水力挙動をシミュレーショ ンし, 後者がBOP, ECCS等の周辺部の挙動をシミュレー ションする。

現在, JACOSの実用に向けた研究の一環として, 同シ ステムを事故時手順の評価に適用するための検討を進めて いる。

以下に現状の運転員モデルの構造, 知識表現と探索法,認 知特性のモデル化を中心に運転員モデルの特徴を概説す る。

\section{（2）運転員モデルの概要}

JACOSでは，原子炉システムに異常が生じた場合，そ れに対好する必要性を検知し，どのように行動するかを決 める認知的振舞いでの情報処理ブロセスの枠組みは， Rasmussenの梯子モデル(29)を基礎としている。このプロ セスを，黒板を用いた分散協調推論手法(黒板モデルと略 す）を用いて計算機上に実装した。この推論手法では， ス ケジューラが推論を実行するエージェントおよび黒板上の 知識の生成/消去を一元的に管理する構造になっている。 これにより，一連の認知的振舞いを複数のサブタスクに分 割し，個々のサブタスクでの情報処理を別々のエージェン トに割り当てて，スケジューラが各エージェントの赛行順 序を制御することで一連の認知過程をシミュレーションす ることができる。また，黒板には，各ェージェントの入出 力結果が書き込まれるが，書き込み可能情報数に上限を設 けるととすに，黒板に書き込まれてから一定時間経過した 情埌は消去(参照不能とする)することで，黒板を短期記憶 領域としてモデル化した。また，エージェントが推論時に 参照する知識を格納する知識ベース (KB と略す)は, 長期 記憶に対応する。

具体的には第 10 図に示すように，一連の認知プロセス を,「監視」,「状態同定」,「目標設定」,「タスク選択」,「手順 選択」の 5 つから構成されるものとし，それぞれに対応す るエージェントを作成した。個々のエージェントが利用す る知識は, シミュレーションする認知行動の形態にあわせ て，2 種類の知識表現でそれぞれの KBに蓄えられ，推論 


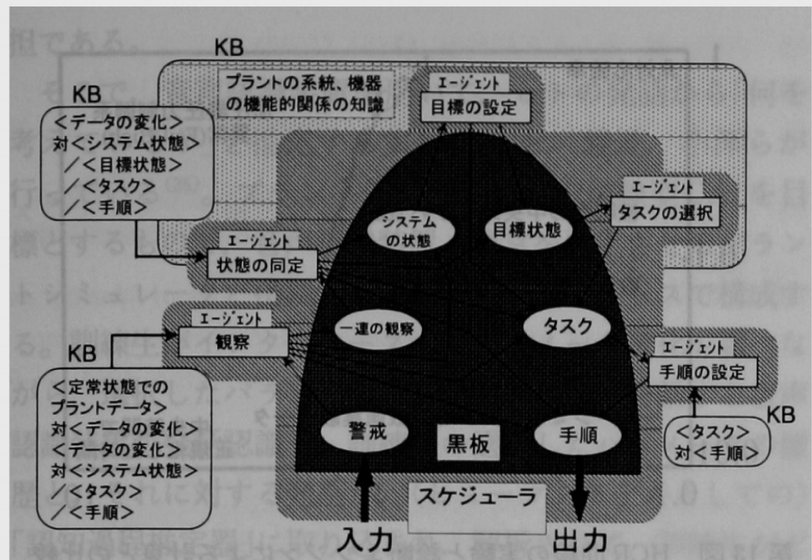

第 10 図 運転員モデルJACOSの概念的構造

実行時に参照される。認知的振舞いの結果である各エー ジェントの推論結果は,「黒板」上に書かれる。 $5 つ$ つ 「ェージェント」の出現順序, 黒板上の情報の消去は, 認知 特性を組み込んだ「スケジューラ」が管理する。

\section{(3) 知識表現}

運転員モデルでは，原子炉の異常時において運転員が用 いる知識として次の 2 種類を考える。一つは, ルールベー ス行動で用いる運転手順の知識, 経験から得られた運転の ノウハウについての知識, など(手続的知識と呼ぶ)であ る。あう一つは, 手順的知識にない状況に直面したときに 採る知識ベース行動のためのシステム機能特性についての 知識あるいは物理法則などの一般的な知識(機能的知識と 呼ぶ)である。以下に, それぞれの知識の表現方法と，そ れをどのように探索するか，その概略を述べる。

\section{(a) 手続的知識}

手続的知識を用いるルールベース行動は, 第10図に示す ように,「観察」,「状態の同定」,「手順の設定」エージェント が行う推論でシミュレーションされる。そこでは, 入力情 報と出力情報が直接結び付く知識が使われる。例えば「状 態の同定」では，異常徵候のパターンを表す「データの変 化」のセットと,「システムの状態」「目標状態」あるいは 「タスク」の関係についての知識を基に，「一連の観察」と異 常徴候のパターンの照合結果から関連する情報を出力す る。このような知識は, If-then ルールのように,「“A”と “B”は関係がある」と表現し，探索は“A”を含む知識を探し 出し、“B”を推論結果として出力する。

(b) 機能的知識

これまでの経験に基づく知識では対応できない不慣れな 状況では, システムの機能的な特性についての知識あるい は物理法則などの一般的な知識を基に，対応することにな る。ここで参照する知識を表現する枠組みとして M. Lind の提唱する Multilevel Flow Modeling(MFM) ${ }^{(30)}$ を用い た。ここでは，熟練した運転員は，MFMで表現できるよ うな構造化された機能的知識を持っており，その知識を定 性推論で探索すると仮定して，知識べース行動をモデル化 した。

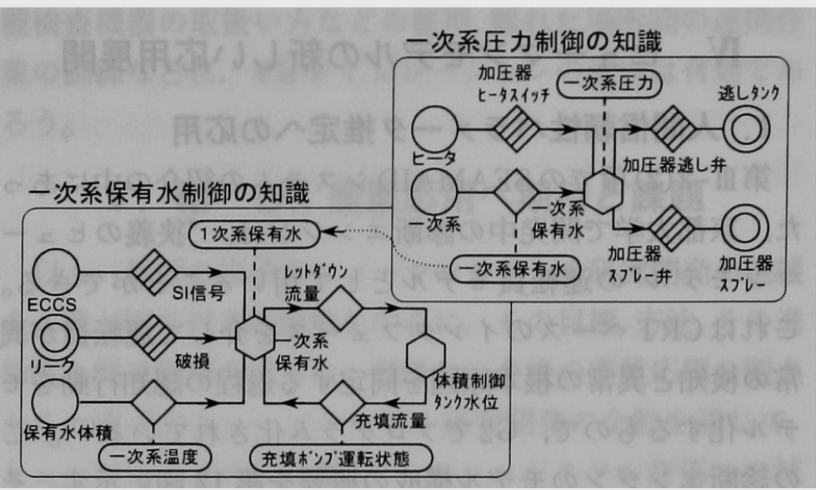

第 11 図 MFMを用いた知識表現の例

第 11 図に知識の表現法の具体例としてPWR の圧力制 御の MFMを示す。六角形は質量あるいはエネルギーの眝 蔵を表す。具体的には, 制御目標となる主要なプラントパ ラメータが対応する。○（○，৩および○は，それぞれ質 量/エネルギーの「ソース」「シンク」,「移動」および「障壁」 を表す。これらの要素を結ぶ矢印の付いた線分は，通常の 質量/エネルギーの流れ方向を表す。この MFM 上での定 性推論の進め方は, 例えば, 制御目標が減少している場合 は, 減少しているソース側の要素, あるいは増加している シンク側の要素が原因であると推論する。原因と考えられ る要素が, 他のMFMの制御目標として表現されているな ら，探索はそのMFMに移動しそこで同じように進められ る。MFM間での移動は, 各 MFMが表す機能の抽象/具 体, 部分/全体のレベルには制約されない。第11図に示した 例では, 「1 次系圧力」の诚少が「 1 次系保有水」の減少に原 因があると推論されると，探索は，「1次系保有水」制御の MFMに移り，「1 次系保有水」を減少させる要素を探す。

（4）認知特性のモテル化

運転員モデルでは，認知的振舞いを長期記憶と短期記憶 での情報処理として扱っている。これらの記憶は，このモ デルでの知識ベースと黒板に対応する。この情報処理過程 で運転員の認知的エラーの潜在的要因として, 一つは必要 な情報の欠落/不正，すう一つは情報の不適切な処理が考 えられる。前者は, 解析条件として知識べース内の知識, 原子炬モデルからのデータを操作することで容易にシミュ レーションできる。後者については, (a)確認バイアスに 起因する注意の狭窄，(b)最近性/最頻性に基づく長期記憶 からの知識呼出し特性, (c) 短期記憶の時間的/容量的制限 の 3 つについて簡単な情報処理の制御でモデル化してい る。

\section{(5) モテルの検証}

JACOS の開発では, 検証 (V \& V : Verification \& Validation)のうち, システムが仕様通りに作成されてい るかを検討するVerificationを行った。主蒸気管破損事 故, 圧力制御系の故障等を例題にシミュレーションを行い, その結果の定性的な妥当性を確認した。シミュレーション 結果の詳細は，文献(2)を参照されたい。 
IV. ヒューマンモデルの新しい応用展開

\section{1.人間信頼性パラメータ推定への応用}

第吕-2(2) 項での SEAMAID システムの紹介の中にあっ

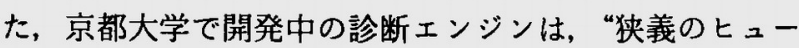
マンモデル゙の運転員モデルとして用いることができる。 これはCRTベースのインタフェースを介して運転員が異 常の検知と異常の根本原因を同定する過程の認知行動をモ デル化するむので，G2でプログラム化されている(31)。こ の診断エンジンのモデル構成の概要を第 12 図に示す。そ の特徵は大略，以下の通りである。

(1) マンマシンインタフェース(MMI)に表示されるプ ラントパラメータとこれの組合せで構成される異常仮 説とをノードとし，ノード間のリンクで構成される異 常仮説検証のための因果ネットワークを，プラントサ ブシステムごとに適当に分割し，異常診断知識べース に蓄積(長期記憶に対応)

（2）頻度による賭(Frequency gambling)を記憶想起の メカニズムとして，MMI 上のパラメータ選択と異常 仮説の想起を行うと仮定

(3) プラントパラメータおよび異常仮説のノードに主観 的確信度を与える。各仮説/ードの確信度は，各プラ ントパラメータに対するメンバシップ関数から，ファ ジイ論理で求める。

Wuらは，実験室規模のプラント異常診断模擬実験 ${ }^{(33)}$ の 被験者データ(被験者はメーカの原子カプラント制御技術 者)をもとに，原子力のプラントPSA/HRAに用いる人間 信頼性パラメータである HRA 曲線 (Human Cognitive Reliability Curve：人間の認知信頼性の時間依存性曲線, いわゆる時間一信頼性トレードオフ)について，実験デー タから導出した HCR 曲線と, 診断エンジンをプラントシ ミュレータに接続したシミュレーションによる HCR 曲線 とを比較している(31)。この実験とヒューマンモデルによ るシミュレーションの対比の 1 例を第 13 図に示す。これ は, PWR の加圧器制御系異常の場合で, 図中の横軸は, 同一事象について，異なった被験者，あるいは同じ被験者 の異なった試行から得た，異常を検知してから，その異常 の根本原因を正しく同定するまでの時間を，元の実験デー

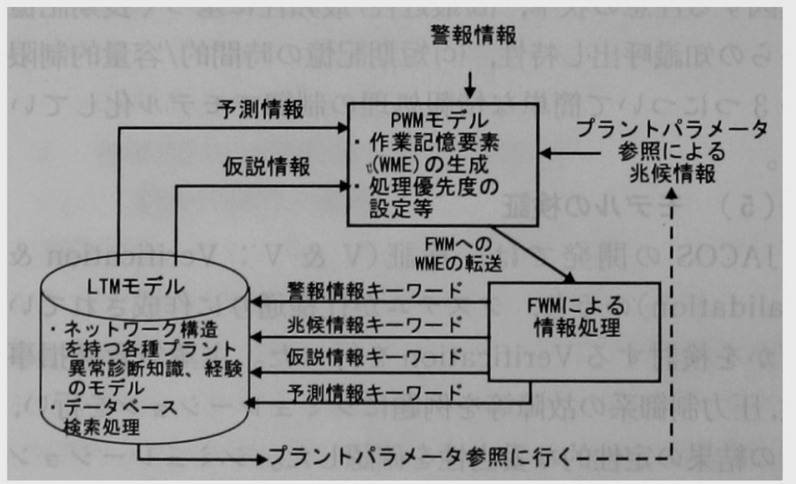

第 12 図診断エンジンの構成と処理フロー

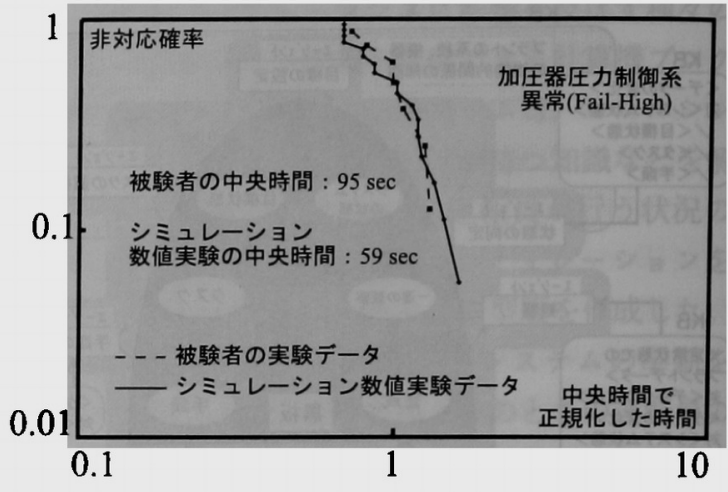

第 13 図 HCR曲線の実験と診断エンジンによる計算との比較

タとしてこれを各実験データのメディアン(この単位は 時間)で正規化したるのである。また，繸軸は非対応確率， すなわち非信頼度に相当する。この HCR 曲線の勾配が急 なほど，誰がやっても，また同じヒトが何度試行しても同 じ結果を示し，一方，この勾配が平坦に近いほど，ヒトに よりまた，同じヒトでも試行のたびに結果が変動するこ とを意味する。第13図での勾配の比較より，診断エンジン によるシミュレーション結果は, 実験で観察される変動性 を比較的再現している。この場合, 人間行動のランダム性 は, (a) プラントパラメータの確認頻度やその順序の相连. (b) パラメータの異常兆候から想定される複数の異常仮説 をいずれから検証し始めるかの相違，(c)一つの仮説成立 の確認後に他の仮説の成立す確認する慎重さの有無，など の要因で生じるが，診断ェンジンを用いて，このような変 動性を入れたモンテカルロシミュレーションにより，実験 データの傾向を再現できることを示した。この研究は, 診 断エンジンの実験検証の側面ああるが，このようにヒ マンモデルで人間信頼性解析用パラメータが推定可能な見 通しを初めて示したものといえる。

\section{2. 音声認識を用いた認知過程推定}

第 II 章の第 1 図に示した枠組み中の，ヒューマンモデル に関わる情報行動計測の研究事例に移る。情報行動の計測 では, 機械がヒトの内面過程をどれだけ追跡推定できるか が課題になる。

高橋らは認知課題試行中の, 被験者の複数生理指標(心 電図, 皮唐電位, 呼吸曲線など)を同時オンライン計測し短 時間波形の特徽的変動をもとに，二ューラルネットで認知 状態をリアルタイム識別して，上卜の内面状態が，(a)情 報受入れに集中, (b)思考に集中, (c)行動開始の意思決定, のいずれかを区別可能な見通しを示した (32)(33)。また，最 近, 黒岡らは脳波解析により, ヒトの問題解決過程で, (a) 正解にたどりついたか，(b)解決の系口は撋めてもなかな か正解にたどり着けないか，(c)皆目，解決の糸口すら見 えない，が識別可能なことを示した ${ }^{(34) 。}$

しかし，生理指標の計測では，認知行動時の心的状態の 区分は可能としても，具体的に「何を考えているのか」はわ からない。また電極を多数張り付けるのは七トにとって負 
担である。

そこで，音声認識装置を用いて，ヒトの発話から「何を 考えているか」を推定する実験研究を，最近，小澤らが 行っている ${ }^{(35)}$ 。プラント異常猃断知識の体験型CAIを目 標とするすので, 音声認識装置, 異常を発生させるプラン トシミュレータと接続した教示用インタフェースで構成す る。訓練生がインタフェース上のパラメータ变化を調べな がら, 選択したバラメータの変化具合の判断を話すと音声 認識装置が発話認識し, 訓練生の選択したパラメータの履 歴と，それに対する発話が，（ヒューマンモデルとしての） 「認知過程推定器」に取り込まれ，解析されて，訓練生がど の程度, 異常の根本原因を絞っているかを, 時々刻々，推 定する。このヒューマンモデルは, 第 IV-1 節でのWuら のモデルと同様な,プラントパラメータ間の因果ネット ワークを基本に，インタフェース上で訓練生が選択したパ ラメータを注目しているパラメータとし, 次いで選択した パラメー夕に対する異常仮説の確信度を発話形式加ら推定 する。すなわち，ヒ卜の操作や発話がヒューマンモデルの 入力となり，「何を考えているか」を推定して出力する，才 ンライン型のモデルである。最近の音声認識装置の急速な 進歩を考えると実見も困難でないが，知的 CAI としては， その推定結果に応じヒ卜に適切なアドバイスを返す機能が 必要である。

\section{3. 保守作業への応用}

保守作業への応用では，第吕-2(2) 項に紹介したSEAMAIDでプラントシミュレータを外したシステム(DIAS) がある。中川らは，原子力発電所変圧器保護リレ一盤の室 内配置および操作パネル盤の改造に，実際にDIASを使用 した ${ }^{(36)}$ 。これは，保守作業手順をぺトリネットでモデル 化して, 保守員の作業時の動きを忠実にシミュレーション し, その過程のヒューマンエラーの可能性をエラ一確率, エラーをした場合のプラントへの影響を多角的に評価する あのである。原子力発電所だけでなく一般ブラントには多 数の保守用操作盤があるが，これまで特に有効な上ューマ ンェラー防止対策がされているわけでないので，DIASの 上うな方向は産業応用が多いものと思われる。

原子力発電所の保守作業では，機械システムの定期的分 解点検が義務づけられており, 原子力発電所機器の保守点 検技術の訓練が，保修訓練センターで行われている。プラ ントには定期点検の対象機器の種類之数の多いことから， それぞれ異なった機器の構造理解, 分解·組立手順の修得用 にVRシミュレーションによる疑似体験型訓練が有効とし て，VRを用いた機器の保修訓練システムが提案されてい る。石井，山本らは，保守作業での「ヒ卜と機械のインタラ クション」のモデル表現法としてペトリネットモデルを応 用している( ${ }^{(37)(38)}$ 。現状のVR支術ではりアルな力覚や触 覚のフィードバックが実現困難で，感覚的なスキルの訓練 には限界があるとの指摘むあるが，実作業前のリハーサル 訓練, 分解点検につきものの異常䇢所の同定, 原因究明の各
種検査機器の取扱い方などの修得, 離れた場所間の連携作 業の訓練などに, VRシミュレーションの活用は有効であ ろう。

\section{V. 結 び：産業応用へ期待と課題}

以上，最近の原子力七ューマンモデルの研究開発の進展 を，我が国の代表的事例を中心に，その目標，方法，その進 捗度と将来展望を述べた。最後に，今後の産業応用の観点 から, 原子力ヒューマンモデル研究開発の全般を通じて, ヒューマンモデルの分類, マンマシンシステム評価への技 術課題, モデル検証について述べる。

原子力分野のヒューマンモデル研究は，プラント制御室 の運転員あるいは運転クルーを対象にしたモデルに止まら ず，保守分野などへる広く展開されている。ヒューマンモ デルは，様々な分類が可能であるが，産業応用の観点から は，静的モデルと動的モデルとに区分できる。

静的モデルは，各種の作業環境下で観察される人間(運 転員，作業員など)の行動を分類し整理したモデルであり，

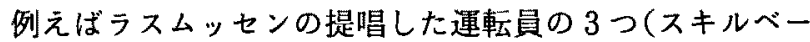
ス,ルールベース, 知識ベース)の行動モデル ${ }^{(39)}$ などが該当 する。このような静的モデルは，マンマシンシステム設計 の概念的な枠組みを決定する初期の段階で応用可能であ る。例えば，前記した運転員の行動モデルは，原子カプラ ントの自動化範囲とそのレベル，CRT 表示装置等を含む中 央制御盤への提供情報の内容，運転支援情報の内容などの 決定段階で参考となる。また，保守作業現場における作業 員の行動形成要因を分類·整理した結果などは，いわ的 ヒニーマンモデルとはいいがたいが，人的過誤防止の観点 から，現場機器の設計やその配置などへの知見として利用 できる。

他方，動的モデルは，運転員の認知モデルに代表される ように，人間の認知行動をモデル化したものであり，例え ば第正章で紹介されている多くの研究事例が該当する。こ れらの動的モデルは，プラントダイナミックスのシミュ レーションモデルおよび，マンマシンシステムの設計デー タベースと結合し，設計されたマンマシンシステムの評価 に応用することが期待される。例えば，中央制御室の新し い制御盤の設計・評価では，最終段階においてプラントシ ミュレータを利用して，実機運転員によるユーザビリティ 評価を行うこ之があるが，時間的制約から評価ケースを较 り込む必要が生ずる。これらの段階で上記の動的モデルを 効果的に導入できれば, 評価の範囲・樑さは大幅な向上が 期待できる。

評価可能な範囲は，一般的には，プラント運転の大半を 占める通常時(起動·停止時を含む)，および希ではあるが 短時間に的確な判断之対応が要求される異常時·事故時之 が含まれる必要がある。

評価内容としては，(1)CRT等の表示装置・操作スイッチ などを含む制御盤の空間的な配置とワークロードとの関 
連，(2)運転操作手順とプラントパラメータへの影響， (3) プラント警報・プロセス状態情報・運転支援情報など提供情 報の範囲・内容・表現形態・タイミング等と運転員の状況認 識能力との関連など，が定量的に把握可能之なれば， ヒューマンモデルの適用範囲は，大幅に拡大されることが 期待できる。

次に，ヒューマンモデルをマンマシンシステムの評価に

応用する上での技術課題について述べる。

まずは，モデル化範冊の拡大である。現段階では，小規 模の設計評価に応用されつつあるプロトタイプは存在する が, 実機設計の評価に応用可能な本格的な認知モデルは, 今後の開発に期待するところが大きい。

次には, 認知モデルの対象者の拡大である。認知モデル の開発対象は，まずは運転員個人であろうが、いうまでも なく運転クルーは，複数の運転員で構成された集付であ り,ベテラン・若手が存在し、これらの中には管理上の階 層関係す存在する。したがって,これらの関係・成員の特 性を含む，現実的な集団を対象とした認知モデルの開発が 望まれる。

最後は，開発したヒューマンモデルの检証である。開発 したモデルが，どの程度実際の運転員の認知的な振舞いを 模擬できているかを，実証することが必要である。吉川， 古田が指摘(1)しているように, ヒューマンモデルの検証 には，物理的モデルの検証とは異なる多くの困難が伴う が、まずは小規模でも特定の分野を対象にして実証するこ とが，重要な課題ではなからうか？検証とモデル改良を 重ね，モデルの有効性を示し，段階的に対象領域を拡大し ていくことにより，順次実設計評価への応用が普及してい くものと期待される。

\section{一参考文献一}

(1) 吉川榮和, 古田一雄: 原子力誌, 36 (4), 268 278 (1994).

(2) Corker. K. M. : Proc. ANS Topical Meeting on Nucl. Plant Instrumentation Control and Man-Machine Interface Technol., Knoxville, (1993).

(3) Furuta, K., Kondo, S. : Int. J. Man-Machine Studies, 39 (3), 473 (1993).

(4) 古田一雄, 他：ヒニーマン・インタフェース研究論集, 4 [2], 91 (1995).

(5) 古田一雄, 他: 原子力誌, 38 (1), 65 (1996).

(6) Furuta, K., et al. : Proc. Int. Conf. on Probabilistic Safety Assessment and Management, Crete, Greece, 15 (1996).

(7) 古田一雄, 吉村誠一: Human Technol., 1 (8), 121 (1997).

(8) 古田一雄: 人工知能誌, 13 [3], 20 (1998).

(9）古濱 寛, 他：第12回ヒニーマン・インタフェース・シンボジウ 么論集. 329 (1996).

(10) 苧阪直行：“意識とは何か”, 岩波書店, (1996)。

(11) Suchman, L. : "Plans and Situated Actions", Cambridge Univ. Press, (1987).

(12)海保博之, 編：“プロトコル分析入門”，新曜社， 58 (1993).
(13) 古田一雄, 他: 人工知能誌, 13 [5], (1998).

(14) 古田一婎: Human Interface $N \& R, 12$ (4), 443 (1997).

(15) Fujita, Y., et al. : Proc. PSAM-II, San Diego, USA, 20 25 Mar, 1994, Vol.2, p.060-13 (1994).

(16) G2 リファレンスマニュアル, 伊藤忠テクノサイェンス, (1993).

(17) Sakuda, H., et al. : Proc. 1996 ANS Int. Topical Meeting on Nuclear Power Plant Instrumentation. Control and HumanMachine Interface Technologies, Pennsylvania, USA, 6 9 May 1996, p.1167 (1996).

(18) Yoshikawa, H., Nakagawa, T., Nakatani, Y., Furuta, T., Hasegawa, A. : Contr. Eng. Practice, 5 [3], 417 425 (1997).

(19) 中川隆志, 他: 㖕测自動制御論集, 33 (8), 834 (1997).

(20) Reason, J.: "Human Error", Cambridge Univ. Press, (1990).

(21) 吉村誠一, 高野研一, 佐相邦英：計測自動制御論集, 31 [2], 227 $\sim 235$ (1995).

(22) 吉村諴一, 高野研一, 佐相邦英：計湘自動制御諭集. 31 (10). $1754 \sim 1761$ (1995).

(23) 柳田邦男: “恐怖の 2 時間18分”, 文芸春秋, 50 53 (1983).

(24) 長谷川尚子, 吉村誠一：原子カブラント運転貣の情動が認知 行動に及ばす影轘, 電中研調查報告, S97001, (1997).

(25) 吉村誠一, 長谷川尚子：Human Interface $N \& R, 12$ (4), 469 (1997).

(26) Hasegawa, N., Yoshimura, S. : Human Machine Cooperation for Emotion Support, Trav. Humain, to be published.

(27) Yoshida, K., et al. : J. Nucl. Sci. Technol., 33 (2), 110 (1996).

Ransom, V. H., et al. : NUREG/CR-4312, (1985).

(29) Rasmussen, J. (海保博之, 他訳)：“インタフェースの認知工 学”, 敬学出版, (1990).

(30) Lind, M. : Riso-M-2357, (1982).

(31) Wu, W., Nakagawa, T., Yoshikawa, H. : Proc. Int. Topical Meeting on Safety of Operating Reactors, Oct 11 14, 1998, San Francisco, p. 79 86 (1998).

(32) Takahashi, M., Wu, W., Yasuta, A., Yoshikawa, H., Nakatani, Y., Nakagawa, T. : Proc. Cognitive Systems Engineering in Process Control, Nov.12 15, 1996, Kyoto, p. 26 33 (1996).

(33) 高橋 信, 北村雅司, 吉川榮和：計測自動制御論集, 30 [6]，548 $\sim 562$ (1994).

(34) Kurooka, T., Kisa, M., Yamashita, Y., Nishitani, H. : Proc. 7th IFAC/IFIP/IFORS/IEA Symp. on Analysis, Design and Evaluation of Man-Machine Systems, Sep.16 18. 1998, Kyoto, p. 539 544 (1998).

(35) 小澤尚久，下田 宏, 吉川樊和：音声認識を用いた認知状態推 定手法のリアルタイム化, 電気学会研究会資料, NE-98-16, (1998).

(36) Nakagawa, T., et. al. : Proc. 7th Int. Conf. on HumanComputer Interaction (HCI International '97), SanFrancisco, California, USA, p.233 236 (1997).

(37) 石井裕剛, 手塚哲央, 吉川榮和: 第14回七ューマン・インタ フェース・シンポジゥム論集, p. 479〜484 (1998).

(38)山本倫也, 市口誠道, 三谷拓也, 手塚哲央, 吉川榮和：第14回 ヒューマン・インタフェース・シンポジゥム論集, p. $453 \sim 458$ (1998).

(99) Rasmussen, I. : IEEE Trans. SMC, SMC-13 (3), 257 (1983). 